\title{
1. China's return migration and its impact on Chinese development
}

\section{Mabel Lu Miao}

\subsection{INTRODUCTION}

As the world enters a new era marked by unprecedented globalization and economic interconnectedness, the world labor market has become increasingly competitive (Laczko and Appave, 2013). In this era of increasingly fierce international competition for talent, the Chinese diaspora constitutes a rich pool of highly qualified individuals who can act as a vital force in helping China to realize its domestic development objectives (Wang, 2009). Were China to effectively tap into this source of talent, it would certainly alter the future world geopolitical balance.

Due to its extraordinarily rapid recent economic growth, the Chinese economy has become the world's largest after the United States. Chinese international migration is also ushering in a transformative stage, which is altering both the political and business landscape of China. The impact it exerts on the country's development can be gauged from the following facts.

In 2013, China ranked number four in the world as a source of migration. The stock of Chinese migrants living abroad increased dramatically by 128.6 percent between 1990 and 2013 - from around 4,086,000 in 1990 to $9,343,000$ in 2013 (Wang, 2014a). China has now become the biggest source of overseas students in the world as well, with the increase in the number of Chinese students studying overseas being especially rapid after 2000. The number of such students rose from 39,000 to 459,800 between 2000 and 2014, growing at more than 20 percent annually during this period (Wang, 2014b). By 2013, the number of Chinese students attending overseas schools and universities stood at just over three million (Wang, 2013b).

Meanwhile, the beginning of the twenty-first century witnessed soaring numbers of overseas Chinese migrating back to China. According to statistics from the Chinese Ministry of Education, in 2014 alone more than 364,800 overseas students came back. In fact, since 2008 , the growth rate 
of numbers of overseas Chinese returnees has exceeded that of students going overseas to study.

The above statistics and facts reveal the development trend of Chinese migration. However, what are the causes that led to Chinese return migration? What are the policy and managerial implications surrounding Chinese return migration? From a strategic talent management perspective, in which sector and to what extent can returnee talent play a leading role in modernizing contemporary China and contributing to the growth of the Chinese economy? These are the guiding questions that we aim to address in this chapter. This chapter draws upon the findings collectively drawn from several recent empirical research projects.

\subsection{CAUSES OF CHINESE RETURN MIGRATION}

\subsubsection{Pull and Push Factors for Returning to China}

Lee's 'push-pull' theory divides the factors causing migration into 'push' and 'pull' categories (Lee, 1966). Push factors basically involve the adverse conditions that make people want to move elsewhere, such as lack of jobs, limited opportunities, political and social chaos, and loss of wealth. Pull factors are things that attract migrants to another area, such as job opportunities, family ties and better living conditions.

In cooperation with Guanghua School of Management, Peking University, the Center for China \& Globalization (CCG) conducted a survey regarding Chinese returnees in 2012. We sent an online survey questionnaire to more than 2,500 persons based on membership data from the Chinese Western Returnees Scholars Association (WRSA). We obtained 356 valid questionnaires. The offline survey was conducted during the 2011 Convention of Overseas Chinese Scholars in Science and Technology in Guangzhou. During that meeting, we got 143 valid questionnaires. So altogether we obtained 499 valid questionnaires. Respondents who took part in the survey had to have studied in the host countries full-time as an undergraduate or graduate student and/or worked there for at least one year. The questions included the motivation for studying abroad and returning, conditions of employment for the returnees, their feelings about studying abroad and experiences while doing so, along with trends in their start-up undertakings and their career development. Although our findings may not generalize to all contemporary Chinese returnees, we believe they are representative of highly educated returnees returning to China to begin new careers or business ventures.

The results of our 2012 Chinese returnee survey show that greater 
economic opportunities and career development are among the main reasons why members of the Chinese diaspora are willing to return to Mainland China. We also find that the return rate is closely associated with the shifting fortunes of the Chinese and overseas economies. After the financial crisis in 2008, while other major world economies were trapped in recession, China's economy remained robust, which created more opportunities at home for Chinese living abroad, therefore spurring the return of some Chinese migrants.

While the global economic downturn can be viewed as a 'push' factor driving the trend of growing numbers of returnee students, the Chinese government has instituted many preferential policies to encourage the Chinese diaspora to return home, which serve as 'pull' factors.

In recent years, the Chinese government has paid unprecedented attention to the development of talent. Particularly worth noting is the launch in 2010 of China's National Talent Development Plan (National Mediumand Long-Term Talent Development Plan, 2010-2020), which forms the cornerstone of China's efforts to tackle emerging talent development issues and ensure that the country has the highly qualified workforce needed to sustain its economic growth engine. This talent plan is the first comprehensive national plan in the history of human resources development in China. It has been devised to exert an extremely powerful influence on the nation's current and future economic and social development in the next decade and beyond. Among the plan's goals is the transformation of China from a manufacturing hub to a world leader in innovation. To meet this ambitious objective, the plan sets forth a very high target for boosting the number of very skilled workers, which is supposed to increase from the current total of 114 million to 180 million by 2020 . At the same time, government spending on human resources development will rise from 10.8 percent of China's gross domestic product (GDP) today to 15 percent by 2020 .

Both the central and local governments in China have recently shown great interest in attracting overseas Chinese talent. The Thousand Talents Program launched by the Chinese government in 2008 represents the latest effort to make China more competitive in the global hunt for top-notch talent. As of summer 2014, more than 4,000 high-quality professionals had returned from abroad to fill positions in the key areas of the Chinese economy and regions of the country most in need of such individuals. The 2011 Thousand Foreign Experts Program has attracted more than 100 non-Chinese top experts.

In line with the central government's talent attracting strategy, by August 2012, 35 industries in 31 provinces and municipalities in China had initiated a total of 2,778 local talent plans. Beijing, for example, has established 
a number of schemes promoting returnee entrepreneurship. In December 2008, it set up an Overseas Students and Scholars Service Center to help recruit overseas Chinese. The best-known example is Beijing's Zhong Guancun Science and Technology Park, which has established 25 incubation centers. By the end of 2011, Zhong Guancun incubation centers had attracted 5,000 companies with more than 12,000 returnee entrepreneurs. Among the returnee Zhong Guancun entrepreneurs, more than 44 percent have obtained patents. Shanghai initiated China's first talent scheme as early as 1992. It is now competing for global talent through the 10,000 Overseas Returnees Cluster Project, which has attracted more than 20,000 overseas returnees who have created more than 4,000 new business ventures. Large cities in coastal regions are much better positioned than other Chinese metropolises to attract overseas returnees.

Our survey also shows that returnees are more likely to be driven by pull factors than push factors in coming home. However, returnees who went abroad after 2000 are more likely to move back because of push factors, such as encountering career development bottlenecks, lack of good job opportunities and the difficulty of integrating into foreign societies.

\subsubsection{Key Factors: Individual Career Development and Family Ties}

In our 2012 Chinese returnee report, we found that career development, family ties and social and cultural identity are the three main reasons for returning. In terms of career development issues, 'have comparative advantages in a professional field,' 'optimistic domestic economic outlook,' 'exploit opportunities in domestic market' and 'attractive preferential policies' rank as the top four factors luring returnees back home. However, less than 35 percent of the respondents returned to China because their career development encountered bottlenecks abroad. And only around 25 percent returning to China did so because of problems in finding a proper job opportunity (see Figure 1.1).

Our research shows that overseas Chinese leave China for better economic and professional opportunities in developed countries and return to China with advanced technology and skills, which then enables them to find good economic and professional opportunities in their mother country. In other words, they return to China for the same reasons they had earlier left the country. The 'brain drain' that had earlier benefitted advanced economies is beginning to be reversed for the benefit of China.

Family ties are another major motivation for returnees to come back to China. In the survey, 70 percent of respondents cited the desire to be back with their families as the main reason leading them to return. However, only around 35 percent of respondents selected the comfort and stability 


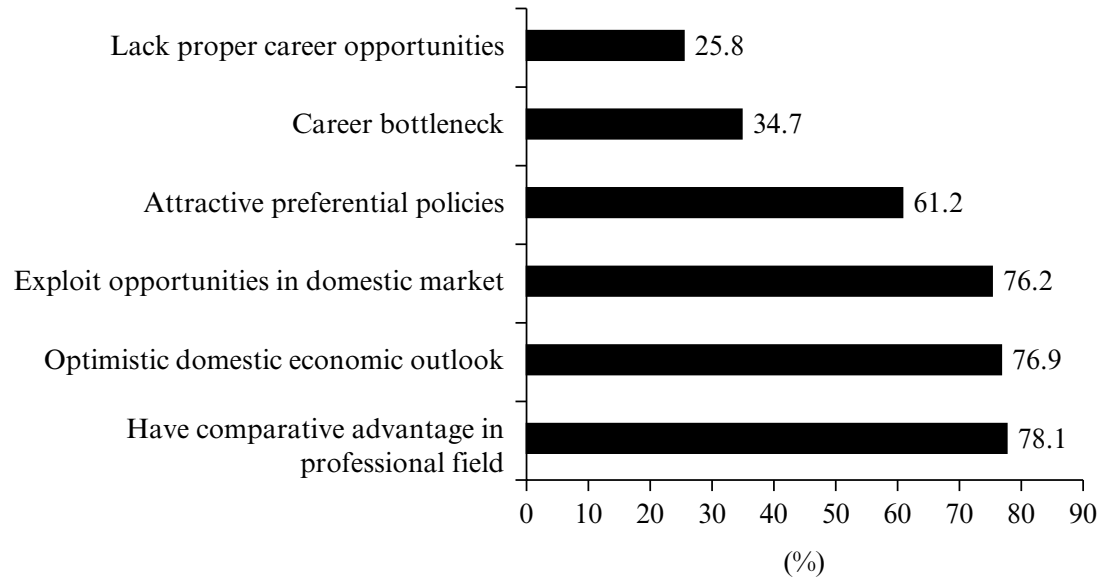

Figure 1.1 Reasons for returning to China (career development)

Life is more comfortable and steady in China

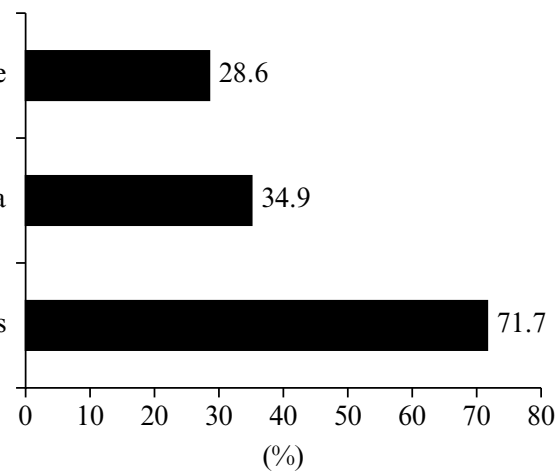

Figure 1.2 Reasons for returning to China (family ties)

of life in China as their main rationale for coming back. An even smaller share (30 percent) said that boredom with living overseas drove them back to the Mainland. This last result may reflect the fact that most of the respondents were between the ages of 30 and 40. These individuals go back to China for the purpose of seeking opportunity and wealth, rather than enjoying pleasure (Figure 1.2).

Moreover, China's culture and stable political environment also seems to be listed as among the main factors drawing overseas Chinese back home. More than 60 percent of respondents cited these two factors as causing them to return to China. However, life stress, loneliness, discrimination 


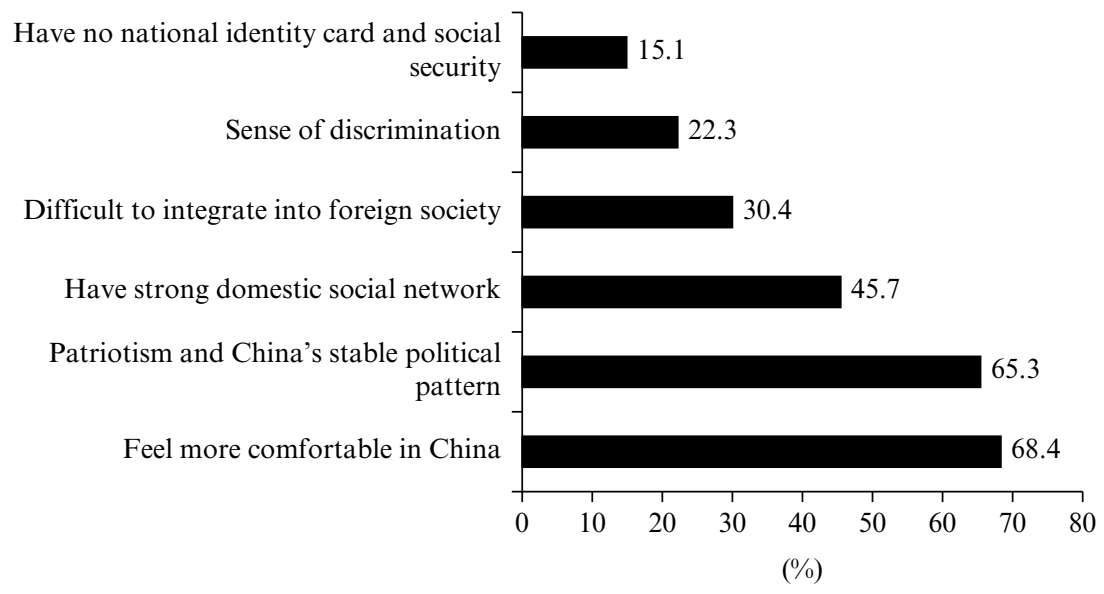

Figure 1.3 Reasons for returning to China (social and cultural factors)

issues and intense intercultural challenges and struggles did not play a significant role in affecting the decision to move back to China. This finding reflects the fact that patience and perseverance are two important Chinese cultural traits. To most Chinese, it is a virtue to survive the demands of a different learning and living environment and to adapt, develop and achieve under difficult and demanding circumstances.

\subsection{CHINESE RETURNEES IN THE BUSINESS WORLD}

\subsubsection{Driving Force of the Returnee Entrepreneurs}

Over the past two decades, China has witnessed the emergence of the formidable economic and technological force of Chinese returnee entrepreneurs. The strong entrepreneurship of contemporary Chinese returnees is the most remarkable difference between these individuals and their predecessors.

The new generation of returnees has become a major driving force behind China's new entrepreneurial movement, directly contributing to the economic development of the country. Most of the returnee entrepreneurs starting their own businesses focus on high-tech and other knowledgeintensive industries, especially in the new generation of IT, biotech, pharmaceutical products and services, and telecommunications and media. At the same time, they have also helped to revitalize many traditional 
industries. In addition, they have introduced many new management concepts and fresh ways of financing business ventures that have promoted the overall development of entrepreneurship in China.

In April 2013, we used both online and offline surveys to investigate returnee entrepreneurship. The online survey collected 199 valid questionnaires, of which 103 were collected from Zhaopin.com and 96 were collected from the Center for China \& Globalization (CCG) and the database of the Chinese Western Returned Scholars Association (WRSA). The offline survey obtained 24 valid questionnaires through the 15th Guangzhou Convention of Overseas Chinese Scholars in Science and Technology and 44 via the 2012 National Overseas Returnees' Entrepreneurship Training Seminar. Thus, a total of 267 valid questionnaires were collected about returnee entrepreneurs, among which 156 were from individuals who had already come back to China to start their businesses, or 58.4 percent of the total surveyed, and 111 who were planning to come back and start their businesses, or 41.6 percent of the total surveyed. The respondents included 196 males and 71 females, representing 73.4 percent and 26.6 percent of the total surveyed, respectively. The data was supplemented with fieldwork, including interviews with returnees, especially returnee entrepreneurs and potential returnee entrepreneurs, to deepen our understanding of the context.

Our 2013 Chinese returnee survey shows that more than 70 percent of returnees chose the cities of Beijing, Guangzhou and Shanghai as well as Jiangsu Province as the places to set up their own companies. Beijing has the largest concentration of returnee companies, accounting for 36.1 percent of the total number of ventures created by these individuals. Beijing is followed by Jiangsu (14.8 percent), Guangzhou (11.5 percent) and Shanghai ( 8.2 percent). But the distribution of returnee entrepreneurial firms is becoming increasingly spread out across China, with some 4.9 percent of returnees choosing to set up businesses in Liaoning, Shandong and Hubei provinces, 3.3 percent selecting Jiangxi and Sichuan provinces and 1.6 percent opting to locate in Zhejiang, Hunan, Guangdong (excluding Guangzhou) and Hainan provinces and the self-governing municipality of Chongqing.

The survey shows that about 52 percent of the businesses started by returnees are in the new generation of IT, biotech and pharmaceutical products and services. Companies involved in devising novel forms of energy and materials account for 9.6 and 6.3 percent, respectively, of the new firms established by returnee entrepreneurs. Our findings also show that the cultural and creative industries are becoming an increasingly important field for returnees in which to start their business, with 13.3 percent of the returnees sampled undertaking new ventures in these areas. 
Most of the firms started by Chinese returnees are in the high-tech sector or high-end services. The leadership teams of these enterprises usually consist of experts possessing the latest scientific knowledge. Due to their close relationship with international companies, advanced management experience and wide-ranging global contacts, they function as a bridge between China's domestic companies and the international market. Since the 1990s, returnee entrepreneurs have significantly propelled the development of domestic high-tech businesses and services, while improving the competitiveness of Chinese enterprises in the global market. More than 260 returnee entrepreneurial start-up parks have already been set up all over China. Indeed, returnee entrepreneurs have changed the domestic business landscape and fostered the development of the new economy.

However, our research also points to the major obstacle faced by Chinese returnee entrepreneurs and a key reason why many of their business ventures fail, namely the absence of adequate financing for such ventures (Wang, 2012a, 2013a). The capital channels for returnee start-up companies consist of government investment, including projects approved by regional high-tech development zones, personal and family savings that can be invested into the business venture, and private capital in the form of domestic/foreign joint venture and venture capital. In our survey, the most important source (46.1 percent) of the initial funding for the new companies started by returnees came from their personal capital, much of which consists of accumulated savings. Private capital, in the form of domestic/foreign joint venture and venture capital, accounts for 20.6 percent of the funds available to support returnee entrepreneur new businesses. Loans from friends and family members, government investment and financial market represent 14.6 percent, 9.7 percent and 4.9 percent respectively. These findings are consistent with the results of a survey of US-educated Chinese and Indian returnee entrepreneurs (Wadhwa et al., 2011).

In our survey, returnees account for 89.4 percent of the presidents of returnee entrepreneurial firms, 75.3 percent of the general managers, and 73 percent of the R\&D directors. Returnees typically play an important role in business and technology development as CEOs or CTOs, while their local core management colleagues are usually responsible for seeing that the technology yields productivity gains. Locals also largely hold managerial positions related to marketing or operations, including being the head of sales/marketing. Other managerial posts held by locals include head of production/operations, human resources and chief financial officer. Returnee entrepreneurs and their local partners may have different kinds of specific social capital consisting of relational and structural resources acquired through a network of social relationships (Kwon and Adler, 
Table 1.1 Distribution of main initial funding sources

\begin{tabular}{llcc}
\hline Sources & & $\begin{array}{c}\text { Percentage of each } \\
\text { part }\end{array}$ & $\begin{array}{c}\text { Overall } \\
\text { percentage }\end{array}$ \\
\hline Personal & Savings & 45.45 & 46.06 \\
Private capital & Intellectual property & 0.61 & \\
& Domestic joint venture & 7.88 & 20.60 \\
& Foreign joint venture & 2.42 & \\
& Domestic venture capital & 7.88 & \\
Family and friends & Foreign venture capital & 2.42 & 14.55 \\
& Loans from friends and & 14.55 & \\
Government & family members & & 9.69 \\
\multirow{2}{*}{ Financial market } & Investment & 8.48 & \\
Others & Subsidy & 1.21 & 4.85 \\
Total & Bank loan & 4.85 & 4.24 \\
& - & - & 100 \\
\hline
\end{tabular}

Source: Annual Report on the Development of Chinese Returnees, 2013, CCG.

2014). Having both returnees and local talent in the entrepreneurial or management team can greatly improve the success rate of entrepreneurship, as it enables the new business venture's management team to make the best use of different kinds of talent to feed on their respective strengths and offset each other's weaknesses.

\subsubsection{Key Players in the Chinese Financial Market}

The Chinese financial market differs from its counterpart in the advanced economies (Ahlstrom et al., 2007). From an institutional perspective, the venture capital industry in China may not possess the appropriate institutional arrangements that can positively affect the development of entrepreneurial ventures (Bruton et al., 2009). The Chinese venture capital market is still a work in progress (Wright, 2007), and the market needs significant development by various actors (White et al., 2005). Returnees have been playing significant roles in reshaping the booming mainland financial market, introducing venture capital and other financial innovations to China. This new fundraising mode has dramatically stimulated the growth of Chinese returnee business and small and medium-sized enterprises (SMEs) in China. They serve as a bridge connecting Mainland China to Hong Kong and other global financial centers and international finance in general. The vision and personal knowledge of returnees is inspiring and 
influencing many Chinese investors. Returnee financial talent has played a major role in establishing China's stock exchange market and reform of its securities industry.

Currently, almost all of the founders of Mainland China-based venture investment companies are returnees. Most of China's high-tech companies listed in Europe and the United States were founded and then brought to overseas stock markets by returnees. Scores of Chinese companies with a total market value of $\$ 60$ billion are now listed on Wall Street. Such firms include famous names like Asiainfo, Baidu, Sina, Sohu, ViMicro, Ctrip, eLong, Shanda, 51job, Kongzhong.com, SunTech Power, New Oriental School, Home Inns and the like. These overseas listed companies have brought advanced technology and talent to China, along with international capital and new mechanisms for managing enterprises and raising capital for them. All these factors will have a significant positive impact on the Chinese people, especially on the younger generation.

A large amount of venture capital has been brought into China by returnees or via foreign-funded companies that had previously employed these individuals. Venture capital is not only a new method of attracting foreign capital, but also an effective capital input mode for China, as it brings new management mechanisms and teams to the country. Venture capital not only stimulates domestic business development, but also promotes the development of the venture capital industry in China.

After their initial successes in China's high-tech industries, a large number of returnees have shifted from being start-up entrepreneurs to being venture capitalists. Compared with other returnee entrepreneurs, they have experience on both the entrepreneurial start-up and financial side of business, giving them a better chance of being successful in their investment activities.

The story of Deng Feng, founding partner of Northern Light Venture Capital, is typical of the individuals we interviewed for this study. Deng went abroad in 1990 and then founded a network security company in 1997, which was listed on NASDAQ in 2001, the first high-tech firm listed on the stock market after the 9/11 attack. In early 2002, he sold his company to another Silicon Valley business for $\$ 4$ billion. This sale received wide attention at that time, as Deng's business was the biggest one founded by a Chinese overseas student in Silicon Valley.

What made Deng shift from being an entrepreneur to being a venture capitalist? In our interview, he said

First, no matter how successful an entrepreneur is, his influence is always limited in one enterprise. But doing VC (venture capital) is different because its influence can cover various fields and even the whole economy. Second, 
in China, venture investments cannot be made without a platform, and VC is a very good platform. In the second half of 2005 I founded Northern Light, basically investing in IT and other early enterprises. Some people wondered why you did VC on your own instead of joining an international company? It's true that there are many chances to join world-class VC firms, but why did I still do it by myself? Because I wanted to create my own venture, Northern Light was my second venture. Generally, VC involves a couple of things, but I did five: first was to reconnect with China, second to reestablish relations, third to organize my own team, fourth to raise funds, and fifth to search for venture capital. I feel that doing one VC undertaking can last for 20 or even 30 years; it's something like a marathon race and one needs to optimize the whole process.

(Wang, 2012b)

Up to now, Northern Light has invested in more than 20 small and medium sized enterprises (SMEs) in China.

Currently, many VC foundation partners are also successful venture capitalists. This new group of managers is playing a significant role in the rapid growth of a large number of SMEs. Chinese returnee entrepreneurs involved in venture capital have been active in fostering the growth of SMEs and then getting these companies listed on overseas stock exchanges, particularly in the US. This activity has reaped big dividends for Chinese venture capitalists, while also enabling the listed companies to make their debut on the stage of global financial markets to be evaluated by overseas investors.

In recent years, Chinese enterprises listed on NASDAQ are not just limited to Internet and high-tech firms - many companies from diverse industries and fields have now been listed. Currently, more than 40 Chinese companies are listed on NASDAQ, with a total market value of $\$ 30$ billion. The managers and leaders of these firms typically have strong international backgrounds. The overseas listed Chinese companies are introducing new technology into China, fresh ways of developing businesses and raising funds from overseas, and transforming traditional industries.

Chinese returnees are the main drivers of the overseas listings of China's high-tech companies in US financial markets. In 2009 alone, a record 33 Chinese companies were listed on NASDAQ, with a total of 124 Chinese companies listed on the stock market. In November 2009, NASDAQ celebrated its 100th listing from mainland China by adding China Nuokang Bio-Pharmaceutical, a healthcare company that provides blood and cardiovascular treatments. Most of the NASDAQ-listed Chinese companies are either funded or run by Chinese returnees. 


\subsubsection{Helping Chinese Enterprises in 'Going Global'}

In recent years, as China implements the 'going global' strategy, some large state-owned competitive enterprises are beginning to appear in international capital markets. Getting listed overseas has gradually become the first choice for Chinese companies going global, especially large stateowned enterprises. Meanwhile, some large private Chinese companies have tried to develop mergers and acquisitions (M\&A) activities overseas to expand their markets. During the overseas listing and M\&A process, people quickly developed a keen appreciation for the important function played by returnees, who have a foot in the door of both Chinese and Western culture and thinking, and possess an acute international vision. One research project on Chinese overseas acquisitions in Europe found that Chinese cross-border M\&A activities adopt the 'light touch' integration management approach, while granting high autonomy to the acquisition target in advanced economies (Liu and Woywode, 2013). Thanks to returnee professional senior managers serving in well-known international investment banks, law firms and certified public accounting firms, overseas listing and M\&As involving up to several dozen billion US dollars could proceed smoothly for large enterprises such as ICBC and CPCC. Among the different strategies adopted by Chinese firms in the pursuit of globalization, talent plays a critical role in facilitating this process (Wang, 2014c).

Returnees play an important role in overseas investment banking and its cooperation with Chinese businesses. To better understand their role and contributions, we interviewed many returnees working in international investment banking (Wang, 2012b). We have also talked with other successful returnees who are working in China's investment banking industry. Liu Erfei, a Harvard MBA of Harvard University and China president of Merrill Lynch, was the first Mainland Chinese individual to obtain a high level position in an American investment bank. Liu oversaw the efforts of a dozen large Chinese state-owned enterprises to go public and was chosen as one of the 'Top 50 Global Investment Bankers' by Global Finance. In October 1999, due to a variety of reasons, the first effort of the China National Offshore Oil Corporation to go public failed. This setback was not only a major blow to the reputation of the company, but also demoralized its staff. By the end of 1999, shortly after Liu joined Merrill Lynch, he was invited to take charge of the oil company's second IPO. Liu declared, 'The market must doubt a second try in such a short time. This time must be successful, no failure is acceptable, and it is a very difficult task. But CNOOC is a very excellent enterprise, and there's no reason for its IPO to fail.' On February 27-28, 2001, CNOOC was listed both on the New York and Hong 
Kong stock exchanges, with these two IPOs amounting to \$2.7 billion combined. Insiders praised this as the most successful IPO of 2001.

With the world's top 500 multinational corporations (MNCs) now operating in China, the demand for talented people with the management skills and transnational networks to bridge the East-West divide has mushroomed. In fact, a McKinsey report, as well as other studies, point out that China currently faces a serious shortage of middle- and high-level managers. As a result, the new waves of Chinese overseas graduates who have already returned, or who work for MNCs or leading companies abroad, have filled many of the top management positions in MNCs, often as in-country directors. The list of MNCs that employ returnees as chief executive officers, executive vice-presidents and other senior posts is impressive and includes Google, Microsoft China, UBS, Alcatel, News Corps, Siemens, Hewlett-Packard, Ernst \& Young, BP and General Motors. Having participated in their company's strategic planning for China, these experienced returnees are able to put new strategies into practice. They facilitate localization, improve the country's overall industrial structure, and help Chinese enterprises move up the value chain in world trade.

\subsection{RETURNEES AS CHANGE AGENTS IN GOVERNMENT, EDUCATION, SCIENCE, CULTURE AND HEALTH}

\subsubsection{Returnees in Chinese Government}

Returnees have participated in Chinese politics since the end of the Qing Dynasty, taking on important jobs in various government bodies throughout China's modern history. In the temporary cabinet of Doctor Sun YaSan, returnees took 15 of the 18 minister and vice-minister positions in the nine government ministries. During the Cultural Revolution, returnees suffered and were forced into silence; however, now they have become active again in the political realm. Compared with their predecessors, the greatest advantage of the new generation of returnees is their professional skill and advanced mindset. They help China integrate with the world in policy design and in the implementation and operation of these policies.

With China's fast-growing economy and concomitant rising international status, communication between China and the rest of the world has increased tremendously. Meanwhile, the country still faces numerous challenges in terms of science and technology innovation. Facing a variety of domestic and international complexities, China has to employ high-quality 
talent with modern professional knowledge and international views, especially those who have studied overseas. Fortunately, in recent years China has made great strides in this aspect.

In 2007, two returnees took ministerial positions in the central Chinese government. Wan Gang was appointed Minister of Science and Technology, while Chen Zhu was appointed Minister of Health. During the first decade of the twenty-first century, the Chinese Central Organization Department has sent nearly 500 top officials to the Harvard Kennedy School for shortterm training and exchanges, including the Chinese Communist Party politburo member and Chinese Vice-President Li Yuanchao.

\subsubsection{Returnees in Education, Science, Culture and Health}

During their time spent abroad, Chinese returnee talent acquired not just advanced degrees, but new knowledge and skills as well. After returning to China, they have successfully leveraged this knowledge and these skills to have a major impact on the country's development in a large and diverse number of areas, ranging from science, technology, agriculture and medicine to business, education, law and politics. Most returnees have kept abreast with the latest international developments and have also been very innovative.

Our survey results show that many returnees choose to make their mark in the fields of education, science, culture and healthcare. In the education sector, statistics from the Chinese Ministry of Education show that 78 percent of the presidents, 63 percent of $\mathrm{PhD}$ advisers in Chinese universities directly administered by the Ministry of Education and 72 percent of directors of key laboratories at the national and provincial levels are returnees. They have not only brought back advanced knowledge to their mother country, but also the latest educational concepts and research methods. The returnees are also influencing the mindset of common Chinese people in other areas such as the press, culture and sports.

They are also participating in many of China's science research projects that are at the cutting edge of global scientific research. Today's returnees have significantly contributed to the creation, improvement and efficient implementation of China's national scientific and technological strategy. Statistics also show that 81 percent of academicians in the Chinese Academy of Sciences and 54 percent of academicians in the Chinese Academy of Engineering have studied overseas. In addition, 21 out of the 23 heroes on the 'two bombs and one satellite' projects are returnees. Their work has lifted the status of China's academics in the world.

Many returnees have won the National Award for Science and Technology. Among the first winners of the National Award for Science 
and Technology, the National Award for Technological Invention and the National Science and Technology Progress Award, 36.9 percent are returnees. Among the winners of the National Award for Science and Technology, 66.7 percent are returnees. Among the winners of the National Award for Technological Invention, 40 percent are returnees. Among the winners of the National Science and Technology Progress Award, 30 percent of the first batches are returnees. This data illustrates the fact that many returnees have become leaders in Chinese scientific and technological research.

In the health sector, the majority of the heads of medical schools and hospitals of Grade 3A (highest grade in hospital classification by the Ministry of Health) in China are returnees. A large proportion of chief physicians - who play a central role in the nation's medical science and research - are returnees. Returnees have likewise made contributions to other sectors including journalism, culture, entertainment and media. They have not only made remarkable scientific achievements, but also pushed for the reform of the education and scientific research systems.

\subsection{DISCUSSION AND CONCLUSION}

This study contributes to the understanding of talent management and Chinese returnee migration in several ways. Firstly, we propose a multilevel framework in examining the driving forces of Chinese returnee migration. From a macro-level perspective, national policy - especially the new talent strategy promoted by both the central government and local governments attracts the movement of talent and returnees. The rapid growth of the Chinese economy in the past three decades can arguably be attributed to the foreign direct investment (FDI) oriented model (Lau and Bruton, 2008). Today's China has shifted its attention to attracting talent with the purpose of enhancing its innovation capabilities and moving up the global value chain in global competition. Talent constitutes the critical factor in the success of this new national strategy (Wang, 2011). From a micro-level perspective, returnee talent is significantly influenced by their social capital (Kwon and Adler, 2014) to determine the location selection and appropriate career choice. Second, becoming entrepreneurs can be perceived as an attractive career choice against the backdrop of China's fast economic growth and lucrative market potential. Returnee entrepreneurs facilitate the globalization of China (Wang, 2012b; Wang et al., 2011).

However, caution is needed in considering the cultural influences and potential reversed cultural shocks facing returnees. Our study identified the process of integrating into the Chinese culture and business environment as being one of the most significant challenges encountered by Chinese 
returnees. It is imperative to recognize and appreciate the cultural differences between West and East. Such differences, in turn, can have an important bearing for both domestic and returnee entrepreneurs (Liu and Almor, 2014). Despite these potential cultural hurdles, Chinese returnees can contribute, from a strategic talent management perspective, to the overall talent pool for Chinese society. Our research reveals the various possibilities for Chinese returnees to influence Chinese economic development and society at large. In particular, the public domain - ranging from government, science and technology to the humanities and healthcare - can profit from the influx and engagement of talent. Global talent management, such as recruitment, retention and utilization for emerging economies (Al Ariss, 2014) deserves considerable attention from scholars, practitioners and policymakers. A strategic perspective on talent management may unleash the potential of talent for China and the rest of the world.

To conclude, China has undergone enormous economic changes in the past 30 years and now faces important decisions on how best to sustain this unprecedented level of growth. While China's past success was built mainly on its population dividend and heavy investment in manufacturing and infrastructure, its future growth will rely more on devising a strategy for making the best use of its talent, both at home and overseas. This will involve luring Chinese talent studying and working abroad back to China. Cheap labor has fueled China's development over the past three decades, but due to the heavy reliance of that growth on old manufacturing industries, heavy use of resources - especially energy - and environmental damage, it is no longer sustainable. China must now shift to a new growth model involving knowledge-based activities, and doing this will necessitate attracting a larger share of global talent to work in the country.

The National Talent Development Plan emphasizes that talent is the top priority resource for China's social and economic development. This new paradigm shift in China's model of development, led by the country's top leaders, has sent a very strong signal that, unlike the past, when much importance was attached to hardware, human talent is now the most valuable and important asset for China to have and cultivate. In the long run, attracting overseas Chinese talent back is just the first step. The crucial issue is devising ways of ensuing that they stay in China.

\section{ACKNOWLEDGEMENTS}

The author would like to thank the editors Professor Huiyao Wang and Dr. Yipeng Liu for their support. The review assistance from Dr. Daniel Garst and Ms. Yang Wei is greatly acknowledged. 


\section{REFERENCES}

Ahlstrom, D., Bruton, G.D. and Yeh, K.S. (2007). Venture capital in China: past, present, and future. Asia Pacific Journal of Management, 24(3): 247-268.

Al Ariss, A. (2014). Global Talent Management: Challenges, Strategies, and Opportunities. Heidelberg: Springer.

Bruton, G.D., Ahlstrom, D. and Puky, T. (2009). Institutional differences and the development of entrepreneurial ventures: a comparison of the venture capital industries in Latin America and Asia. Journal of International Business Studies, 40(5): 762-778.

Kwon, S.-W. and Adler, P.S. (2014). Social capital: maturation of a field of research. Academy of Management Review, 39(4): 412-422.

Laczko, F. and Appave, G. (2013). World Migration Report 2013: Migrant WellBeing and Development. Geneva: International Organization for Migration.

Lau, C.M. and Bruton, G.D. (2008). FDI in China: what we know and what we need to study next. The Academy of Management Perspectives, 22(4): $30-44$.

Lee, E.S. (1966). A theory of migration. Demography, 3(1): 47-57.

Liu, Y. and Almor, T. (2014). How culture influences the way entrepreneurs deal with uncertainty in inter-organizational relationships: the case of returnee versus local entrepreneurs in China. International Business Review, http://dx.doi. org/10.1016/j.ibusrev.2014.11.002.

Liu, Y. and Woywode, M. (2013). Light-touch integration of Chinese crossborder M\&A: the influences of culture and absorptive capacity. Thunderbird International Business Review, 55(4): 469-483.

Wadhwa, V., Jain, S., Saxenian, A., Gereffi, G. and Wang, H. (2011). The Grass is Indeed Greener in India and China for Returnee Entrepreneurs: America's New Immigrant Entrepreneurs, www.kauffman.org/what-we-do/research/immigrationand-the-american-economy/the-grass-is-indeed-greener-in-india-and-china-forreturnee-entrepreneurs.

Wang, H. (2009). Talent War: the Competition for Most Scarce Resources. Beijing: CITIC Publishing.

Wang, H. (2011). China's new talent strategy: impact on China's development and its global exchanges. SAIS Review of International Affairs, 31(2): 49-64.

Wang, H. (2012a). Annual Report of Chinese Returnee Entrepreneurs. Beijing: China Social Science Academy Press.

Wang, H. (2012b). Globalizing China: The Influence, Strategies and Successes of Chinese Returnees. Bingley: Emerald Group Publishing.

Wang, H. (2013a). Annual Report of Chinese Returnee Development. Beijing: China Social Science Academy Press.

Wang, H. (2013b). Annual Report of Chinese Students Study Abroad. Beijing: China Social Science Academy Press.

Wang, H. (2014a). Annual Report of Chinese International Migration. Beijing: China Social Science Academy Press.

Wang, H. (2014b). Annual Report of Chinese Students Study Abroad. Beijing: China Social Science Academy Press.

Wang, H. (2014c). Ten Chinese going global models: emerging patterns and analysis. The European Journal of Finance, 20(7-9): 625-636. 
Wang, H., Zweig, D. and Lin, X. (2011). Returnee entrepreneurs: impact on China's globalization process. Journal of Contemporary China, 20(70): 413-431.

White, S., Gao, J. and Zhang, W. (2005). Financing new ventures in China: system antecedents and institutionalization. Research Policy, 34(6): 894-913.

Wright, M. (2007). Venture capital in China: a view from Europe. Asia Pacific Journal of Management, 24(3): 269-281. 